\title{
Noninvasive evaluation of respiratory muscles in pre-clinical model of Duchenne Muscular Dystrophy ${ }^{1}$
}

\author{
Daniela M. Oliveira ${ }^{2 *}$, Stefano C. Hagen², Amilton C. Santos², Maria A. Miglino² \\ and Antônio C. Assis Neto ${ }^{2}$
}

\begin{abstract}
Oliveira D.M., Hagen S.C., Santos A.C., Miglino M.A. \& Assis Neto A.C. 2016. Noninvasive evaluation of respiratory muscles in pre-clinical model of Duchenne Muscular Dystrophy. Pesquisa Veterinária Brasileira 36(4):290-296. Setor de Anatomia dos Animais Domésticos e Silvestres, Faculdade de Medicina Veterinária e Zootecnia, Universidade de São Paulo, Avenida Prof. Dr. Orlando Marques de Paiva 87, São Paulo, SP 05508-030, Brazil. E-mail: oliveiradm@usp.br

Since respiratory insufficiency is the main cause of death in patients affected by Duchenne Muscular Dystrophy (DMD), the present study aims at establishing a new non-invasive method to evaluate the clinical parameters of respiratory conditions of experimental models affected by DMD. With this purpose in mind, we evaluated the cardiorespiratory clinical conditions, the changes in the intercostal muscles, the diaphragmatic mobility, and the respiratory cycles in Golden Retriever Muscular Dystrophy (GRMD) employing ultrasonography (US). A control group consisting of dogs of the same race, but not affected by muscular dystrophy, were used in this study. The results showed that inspiration, expiration and plateau movements (diaphragm mobility) were lower in the affected group. Plateau phase in the affected group was practically non-existent and showed that the diaphragm remained in constant motion. Respiratory rate reached 15.5 per minute for affected group and 26.93 per minute for the control group. Expiration and inspiration movements of intercostal muscles reached $8.99 \mathrm{~mm}$ and $8.79 \mathrm{~mm}$, respectively, for control group and $7.42 \mathrm{~mm}$ and $7.40 \mathrm{~mm}$, respectively, for affected group. Methodology used in the present analysis proved to be viable for the follow-up and evaluation of the respiratory model in GRMD and may be adapted to other muscular dystrophy experimental models.
\end{abstract}

INDEX TERMS: Respiratory muscles, Duchenne Muscular Dystrophy, diaphragm, DMD, GRMD, ultrasound.

RESUMO.- [Avaliação não invasiva dos músculos respiratórios no modelo pré-clinico da Distrofia Muscular de Duchenne.] Uma vez que, a insuficiência respiratória é a principal causa de morte em pacientes afetados pela Distrofia Muscular de Duchenne (DMD), o presente estudo avaliou as condições clínicas cardiorrespiratórias, o movimento dos músculos intercostais, a mobilidade diafragmática, os ciclos respiratórios e a expansão da cavidade torácica em cães Golden Retriever com Distrofia Muscular (GRMD) por ultrassonografia (US) a fim de estabelecer um novo método não invasivo para avaliar os parâmetros de avaliação clínica de

\footnotetext{
${ }^{1}$ Received on June 11, 2015.

Accepted for publication on January 6, 2016.

${ }^{2}$ Setor de Anatomia dos Animais Domésticos e Silvestres, Faculdade de Medicina Veterinária e Zootecnia, Universidade de São Paulo (USP), Av. Prof. Dr. Orlando Marques de Paiva 87, São Paulo, SP 05508-030, Brazil. *Corresponding author: oliveiradm@usp.br
}

doenças respiratórias de modelos experimentais afetados por DMD. Um grupo controle constituído por cães da mesma raça e espécie, mas não afetados pela distrofia muscular também foram utilizados neste estudo. Os resultados mostraram que os movimentos de inspiração, expiração e platô (mobilidade do diafragma) foram menores no grupo afetado. A fase de platô no grupo afetado foi praticamente inexistente e mostrou que o diafragma destes animais permaneceu em constante movimento. A frequência respiratória atingiu 15,5 por minuto para o grupo afetado e 26,93 para o controle. Movimento de expiração e inspiração dos músculos intercostais atingiu 8,99 milímetros e 8,79 milímetros, respectivamente para o grupo controle e 7,42 milímetros e 7,40 milímetros, respectivamente para o grupo afetado. A metodologia utilizada nesta análise foi viável para o acompanhamento e avaliação do modelo respiratória em modelo GRMD e pode ser adaptado para outros modelos experimentais de distrofia muscular. 
TERMOS DE INDEXAÇÃO: Músculos respiratórios, Distrofia Muscular de Duchenne, diafragma, DMD, GRMD, ultrassom.

\section{INTRODUCTION}

In humans, the Duchenne muscular dystrophy (DMD) is the most serious and common disease that affects muscular tissue (Zatz et al. 2000). DMD is a recessive genetic disease, which affects one in 3,500 male newborns (Oliveira et al. 2013; Santos et al. 2013). This condition is characterized by the absence of dystrophin, an important protein that composes the plasma membrane of muscular cells. This protein promotes the binding of F-actin, which composes the myofilament of striated skeletal muscle cells (Zatz et al. 2000, Michele \& Campbell 2003, Oliveira et al. 2013).

Humans affected by DMD present the inability to walk at approximately seven years of age (Zatz et al. 2000), and over time, the disease affects the spine, nerves, sternum and thoracic cage. The most severe symptoms cause changes in the thoracic cage, which lead to the restriction of pulmonary expansion and to a decrease in gas exchange (Finder et al. 2004, Bezerra et al. 2010, Oliveira 2012). At last, the failure of the respiratory muscles causes the death of individuals by respiratory or cardiac muscular failure at approximately 25 to 30 years of age (Kennedy et al. 1995, Zatz et al. 2000, West 2002, Bogdanovich et al. 2004, Bezerra et al. 2010, Oliveira 2012).

Similarly to humans affected by DMD, Golden Retriever dogs affected by Muscular Dystrophy (GRMD) suffer impairment of the respiratory muscles, specially the diaphragm and intercostal muscles, which leads to progressive respiratory failure (Ambrósio et al. 2008, Oliveira 2012). The Golden Retriever has been used as a model for studies on DMD in the recent years. Among these studies, the ultrasonography (US) has been used as a low-cost test and a non-invasive imaging method to enable the clinical assessment of patients, through the observation of the progress of the echogenicity intensity, caused by the evolution of tissue degeneration, providing efficient clinical data for monitoring these patients (Ahmad et al. 2010, Jansen et al. 2012, Zaidman et al. 2010).

US is frequently used in the investigation and monitoring of musculoskeletal diseases and may be used to assess the progression of muscle loss in DMD due to its capacity to efficiently locate, detect and characterize tissue lesions (Sintzoff et al. 1992, Ahmad et al. 2010, Zaidman et al. 2010, Jansen et al. 2012). Distrophy causes muscle tissue degeneration and the muscular fibers are replaced by adipose tissue and collagen which increase the echogenicity, thus allowing the muscular margins to be determined by ultrasound (Zaidman et al. 2010, Jansen et al. 2012, Oliveira 2012). In recent times, the US also has been employed to monitor the diaphragmatic movements in patients with respiratory diseases (Voyvoda et al. 2012).

Therefore, the present study evaluated the cardiorespiratory clinical conditions, the changes in the intercostal muscles, the diaphragmatic mobility, and the respiratory cycles in GRMD employing B/M mode ultrasonography (US).

\section{MATERIALS AND METHODS}

Animals. Four GRMD-affected (males) and four non-affected GRMD (females) used as control group were used in this experiment. These dogs were between 4 and 5 years old (Table 1). All animals were obtained from the GRMD kennel, located in the Domestic and Wild Animals Anatomy Department, School of Veterinary Medicine and Animal Science at the University of São Paulo (FMVZ/USP), São Paulo, Brazil, according to the regulations and principles established by the Bioethics Committee of the FMVZ-USP (protocol 2609/2012).

Table 1. Selected animals from the Golden Retriever Muscular Dystrophy (GRMD) Kennel Brazil, USP

\begin{tabular}{lccc}
\hline Group & Animals & Age (years) & Weight \\
\hline Control & C 1 & 5 & 26.60 \\
& C 2 & 4.5 & 31.30 \\
& C 3 & 4 & 27.70 \\
Affected & C 4 & 4.5 & 28.50 \\
& A 1 & 4.5 & 17.88 \\
& A 2 & 5 & 18.24 \\
& A 3 & 4.5 & 16.38 \\
& A 4 & 4.5 & 19.50
\end{tabular}

Clinical parameters evaluated. Animals from the control and affected groups were evaluated by a single examiner during all clinical exams, US analysis and laboratory tests. A total of four exams per animal were conducted, with 30-day intervals between exams.

The following parameters were assessed in the clinical evaluation: weight (kg); heart rate (HR) and respiratory rate (RR) per minute; rectal temperature $\left(\mathrm{T}^{\circ} \mathrm{C}\right)$ in Celsius degrees; inspiratory circumference (IC) and expiratory circumference (EC) in centimeters $(\mathrm{cm})$; and the height and width of the thoracic cage in centimeters $(\mathrm{cm})$.

In order to establish the relationship between the anatomical thoracic cage changes to the breathing of the individuals, we used the evaluation of inspiratory circumference and expiratory circumference of the thoracic cage. The circumference of the thoracic cage was obtained using a measuring tape during the process of inspiration and expiration. The height and width of the thoracic cage were measured with a $40-\mathrm{cm}$ aluminum caliper (Konex ${ }^{\circledR}$ ). Temperature and luminosity control tests were performed to establish the respiratory cycles of both groups of animals. The tests were conducted in an environment room devoid of sound and light, with an average temperature of $20^{\circ} \mathrm{C}$.

These data were measured to monitor the evolution and quantification of muscular changes throughout the four experimental evaluations.

Ultrasonography (US). For a better understanding of the characteristics of the images used in the present study, echogenicity was used as a qualitative characteristic to visualize the diaphragm and intercostal muscles. A CHISON US instrument (model D600VET) coupled to a $5 \mathrm{MHz}$ convex transducer was used for these experiments.

US: Diaphragmatic mobility. Diaphragmatic mobility was evaluated through the craniocaudal displacement of the diaphragmatic line. The transducer was positioned in the xiphoid region, with perpendicular incidence to the craniocaudal axis toward the diaphragmatic line. Next, the diaphragmatic line was identified in $\mathrm{B} / \mathrm{M}$ mode field vision. The craniocaudal displacement of these points was considered the diaphragmatic mobility for one cycle. Each respiratory cycle is constituted by an inspiration (I), expiration (E) and plateau phase (Fig.1).

The diaphragmatic amplitude during the cycles was also assessed; thus, the distance (D) was calculated from the maximum 
peak reached in the diaphragmatic mobility to the plateau phase. Three images were obtained, and their mean and standard deviation value were calculated.

US: Intercostal muscles. After identifying the intercostal muscles by US, the muscular contraction and relaxation (in $\mathrm{mm}$ ) were assessed during inspiration and expiration.

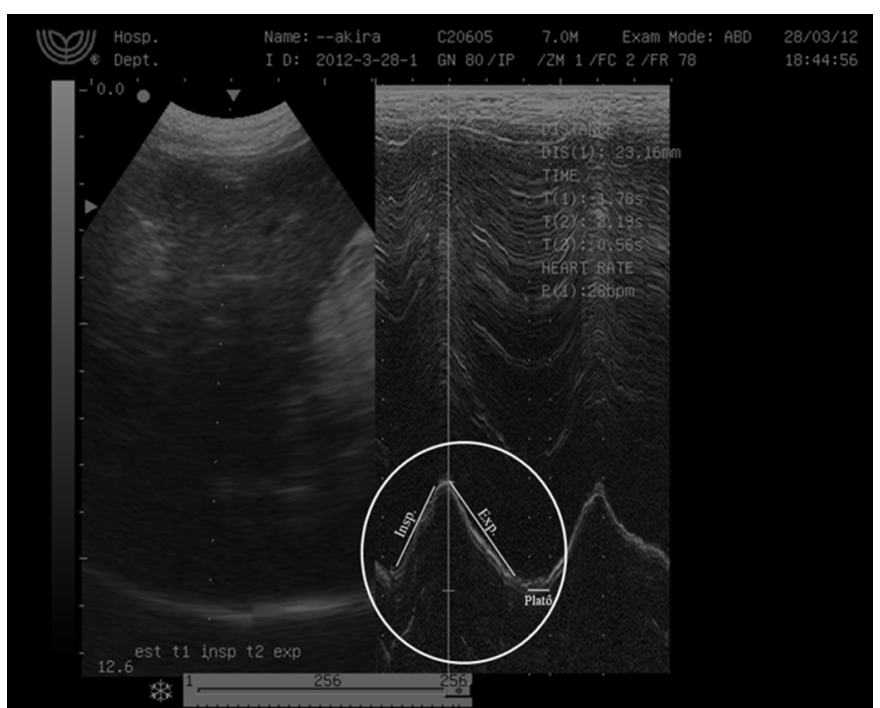

Figure 1. Ultrasonography image of diaphragm mobility: (Insp.) inspiration; (Exp.) expiration; plateau phase or rest phase between one cycle and another. Circle represents diaphragm mobility which corresponds to the phase of the animal's respiratory cycle.

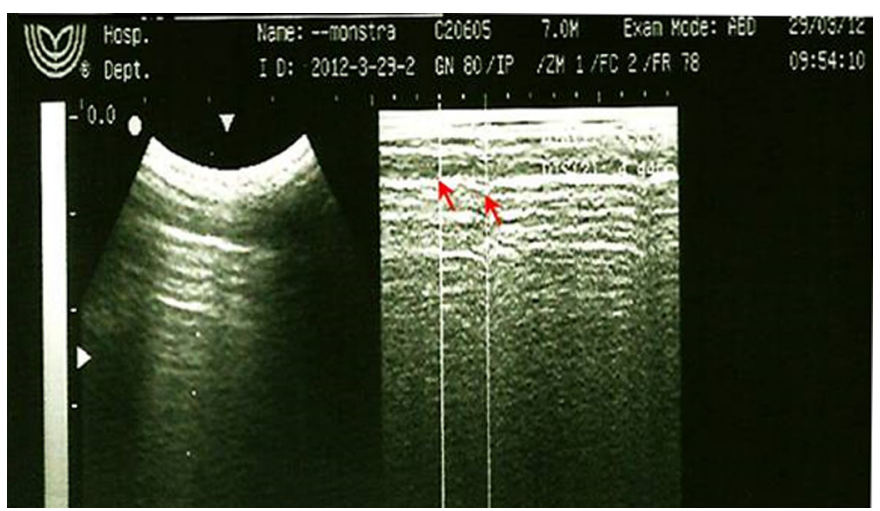

Figure 2. B/M mode US image of intercostal muscles: measurement of muscle contraction and relaxation $(\mathrm{mm})$.
The transducer was positioned vertically in the seventh intercostal space, and two values (inspiration and expiration) were recorded in $\mathrm{B} / \mathrm{M}$ mode in both groups.

Image interpretation was performed during the exam through the dynamic qualitative and quantitative observation of muscle changes. Photodocumentation and statistical analyses were performed to establish the degrees of muscular hypertrophy or atrophy by US, as demonstrated in Figure 2.

Laboratory tests. Every 30 days, $2 \mathrm{ml}$ of blood were collected by venipuncture of the radial vein for hemogram analysis (Matos \& Matos 1988). Disposable glass Vacutainer tubes (13x75mm) with lids containing 10\% EDTA (ethylene diamine tetra acetic acid, disodium salt) in aqueous solution were used (Kerr 2003). Disposable needles (25x8) were used for blood collection. The samples were analyzed in the HOVET Analysis Laboratory of the School of Veterinary Medicine and Animal Science at the University of São Paulo.

Statistical analysis. The results were analyzed, and the mean and standard deviation of the samples were reported.

To validate the respiratory rate obtained through US, the total sum of inspiration, expiration and plateau, provided in seconds by the ultrasound instrument, was calculated. The number of cycles per minute was then calculated according to the following equation:

$\frac{\text { Inspiration }+ \text { expiration }+ \text { plateau }}{60 \text { seconds } / X}=\mathrm{X}$

\section{RESULTS}

\section{Clinical parameters}

It was observed that the $\mathrm{HR}, \mathrm{RR}, \mathrm{T}^{\circ} \mathrm{C}, \mathrm{IC}, \mathrm{EC}$, thoracic mean height $(\mathrm{MH})$ and thoracic mean width (MW) in the control group (Table 2) showed clinical parameters within the normal range; however, in the affected group, the mean of RR was below the normal standard.

\section{US evaluation}

Ultrasound images of the affected and control groups were obtained in different positions: right lateral decubitus, left lateral decubitus and at station, as shown in Figure 3 , in order to establish the differences between positions and to determine which position is the best for this exam.

By analyzing the differences among the positions, it was concluded that the exam presents the most reliable results when the patient is in the right lateral decubitus position, in which the diaphragmatic mobility showed an optimal curve for evaluation of the respiratory cycle.

Table 2. Mean and standard deviation of the control and affected groups: evaluation of clinical parameters

\begin{tabular}{cccccccc}
\hline & HR(minute) & RR(minute) & $\mathrm{T}\left({ }^{\circ} \mathrm{C}\right)$ & $\mathrm{IC}(\mathrm{cm})$ & $\mathrm{EC}(\mathrm{cm})$ & $\mathrm{MH}(\mathrm{cm})$ & $\mathrm{MW}(\mathrm{cm})$ \\
\hline C1 & $129 \pm 7.10$ & $20.50 \pm 7.20$ & $38.30 \pm 0.2$ & $68.40 \pm 0.65$ & $68.20 \pm 0.9$ & $23.70 \pm 0.46$ & $17.70 \pm 0.21$ \\
C2 & $92 \pm 12.00$ & $30.25 \pm 17.36$ & $38.35 \pm 0.38$ & $74.77 \pm 1.89$ & $74.62 \pm 2.53$ & $24.00 \pm 0.64$ & $21.25 \pm 1.30$ \\
C3 & $109 \pm 14.24$ & $23.00 \pm 4.40$ & $37.87 \pm 0.22$ & $72.75 \pm 0.90$ & $72.75 \pm 0.82$ & $24.85 \pm 0.49$ & $18.37 \pm 0.58$ \\
C4 & $91 \pm 10.34$ & $34.00 \pm 3.47$ & $38.42 \pm 0.29$ & $69.95 \pm 1.75$ & $69.37 \pm 1.63$ & $23.87 \pm 0.34$ & $18.60 \pm 0.40$ \\
Mean \pm SD & $105.38 \pm 15.65$ & $26.93 \pm 5.42$ & $38.22 \pm 0.21$ & $71.41 \pm 2.55$ & $71.34 \pm 2.45$ & $24.11 \pm 0.43$ & $18.98 \pm 1.35$ \\
A1 & $88 \pm 6.32$ & $16.0 \pm 0.00$ & $37.85 \pm 0.15$ & $62.00 \pm 0.61$ & $62.87 \pm 0.34$ & $21.92 \pm 0.46$ & $15.8 \pm 0.46$ \\
A2 & $121 \pm 8.18$ & $19.0 \pm 8.19$ & $38.05 \pm 0.29$ & $59.12 \pm 0.54$ & $60.5 \pm 0.86$ & $20.00 \pm 0.70$ & $15.8 \pm 0.46$ \\
A3 & $105 \pm 17.29$ & $12.5 \pm 0.86$ & $37.90 \pm 0.41$ & $62.62 \pm 0.96$ & $63.25 \pm 2.02$ & $20.55 \pm 1.18$ & $16.65 \pm 1.38$ \\
A4 & $103 \pm 8.66$ & $14.5 \pm 1.65$ & $37.77 \pm 0.33$ & $62.25 \pm 1.15$ & $63.5 \pm 1.17$ & $22.65 \pm 0.40$ & $16.2 \pm 0.50$ \\
Mean \pm SD & $104.25 \pm 11.69$ & $15.5 \pm 3.38$ & $37.91 \pm 0.10$ & $61.5 \pm 1.38$ & $62.53 \pm 1.19$ & $21.28 \pm 1.05$ & $15.63 \pm 0.35$
\end{tabular}

$\overline{\mathrm{A}}=$ affected, $\mathrm{C}=$ control, $\mathrm{HR}=$ heart rate. $\mathrm{RR}=$ respiratory rate, $\mathrm{T}^{\circ} \mathrm{C}=$ temperature, $\mathrm{IC}=$ inspiration circumference,

$\mathrm{EC}=$ expiration circumference. $\mathrm{MH}=$ thoracic mean height, $\mathrm{MW}=$ thoracic mean width. 


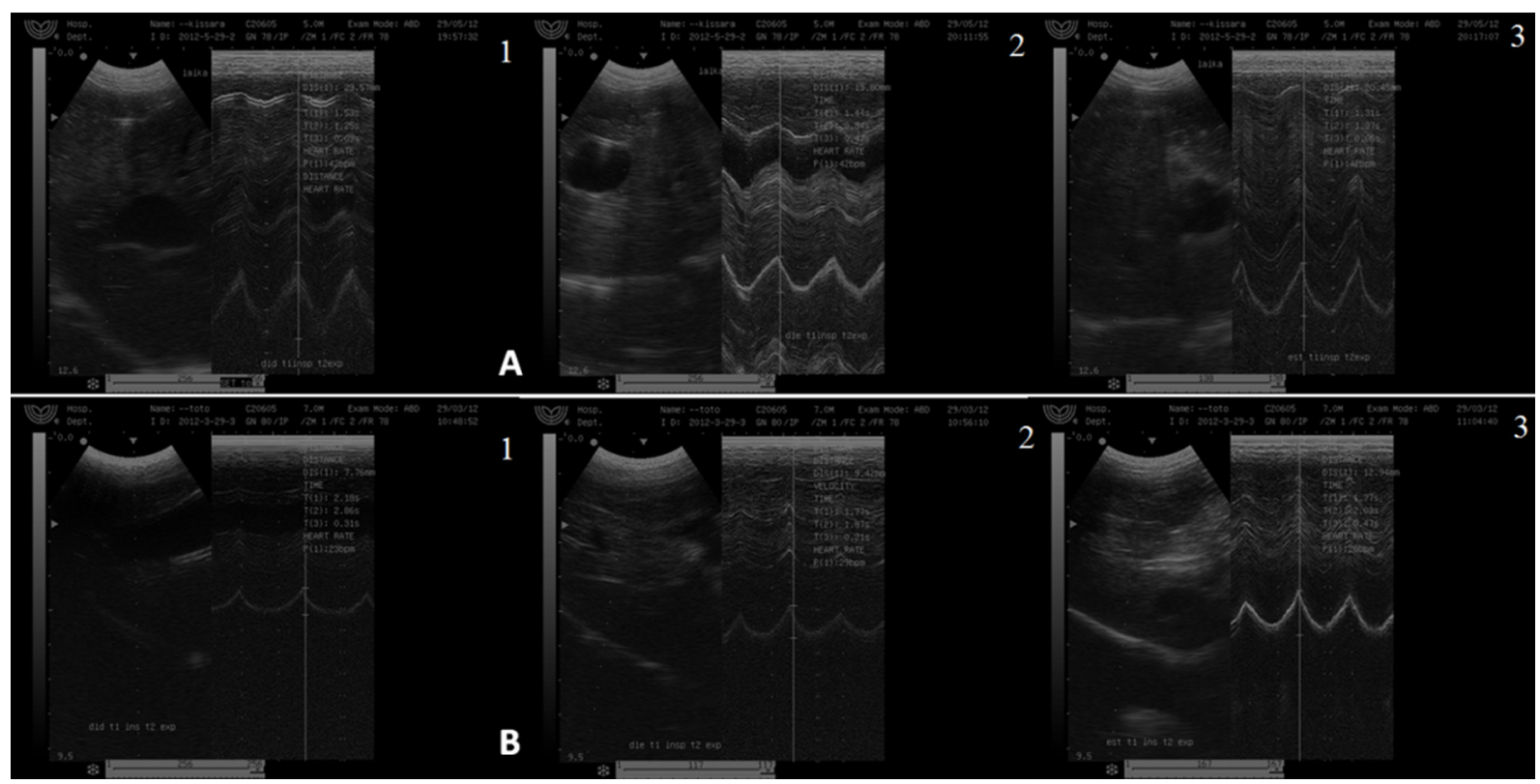

Figure 3. Ultrasound image of the diaphragmatic mobility of the control (A) and affected (B) groups at different positions: 1. (RLD) right lateral decubitus; 2. (LLD) left lateral decubitus; 3. (S) animal at station. "A" represents a sequence of ultrasound images of an animal from the control group. "B" represents a sequence of ultrasound images of an animal from the affected group. Notice the differences in the respiratory pattern of the two groups.

Table 3. Mean and standard deviation of the diaphragm mobility of control and affected groups by US analysis

\begin{tabular}{ccccccc}
\hline & Dist $(\mathrm{mm})$ & Insp(sec) & Exp(sec) & Plateau(sec) & C. Cycle(sec) & RR(min) \\
\hline C1 & 19.18 & 1.52 & 1.63 & 0.32 & 3.4 & 17.6 \\
C2 & 16.75 & 1.23 & 1.50 & 0.17 & 2.9 & 20.7 \\
C3 & 17.3 & 1.37 & 1.31 & 0.16 & 2.8 & 21.4 \\
C4 & 15.72 & 1.37 & 1.23 & 0.18 & 2.9 & 20.7 \\
Mean \pm SD & $17.24 \pm 1.26$ & $1.37 \pm 0.10$ & $1.49 \pm 0.17$ & $0.21 \pm 0.07$ & $2.87 \pm 0.41$ & $20.05 \pm 1.70$ \\
A1 & 13.61 & 2.56 & 2.32 & 0.21 & 5.9 & 9.8 \\
A2 & 12.17 & 2.26 & 2.30 & 0.64 & 5.2 & 11.6 \\
A3 & 14.40 & 2.50 & 2.49 & 0.12 & 5,1 & 9.8 \\
A4 & 11.98 & 3.37 & 2.50 & 0.33 & 6.2 & 9.7 \\
Mean \pm SD & $13.04 \pm 1.01$ & $2.67 \pm 0.42$ & $2.4- \pm 0.11$ & $0.32 \pm 0.20$ & $5.65 \pm 1.03$ & $10.22 \pm 1.00$
\end{tabular}

$\overline{\mathrm{A}}=$ affected, $\mathrm{C}=$ control, Dist $=$ distance, Insp = inspiration, Exp = expiration, $\mathrm{C}=$ complete, $\mathrm{sec}$ $=$ seconds, $\min =$ minute .

\section{Diaphragmatic mobility by US}

Important data that differentiate the respiratory pattern between the two groups were noted in the present study. As for diaphragmatic mobility, the distance is greater in the control group and smaller in the affected group (Table $3)$. Moreover, the inspiration and expiration curves of the affected group are characterized by a larger pattern than those of the control group. The plateau state was larger in the control group and smaller in the affected group. This differentiated pattern between the groups shows a change in the respiratory cycle of the animals from the affected group.

\section{Clinical respiratory rate (RR) $\mathrm{x}$ respiratory cycle (US)}

Comparing clinical and US analysis, the control group maintained a stable respiratory cycle, with equivalent rates of inspiration, expiration and plateau, while the affected group showed an unstable cycle, with greater inspiration and expiration rates and a smaller plateau state.

The respiratory cycle was assessed, showing that the

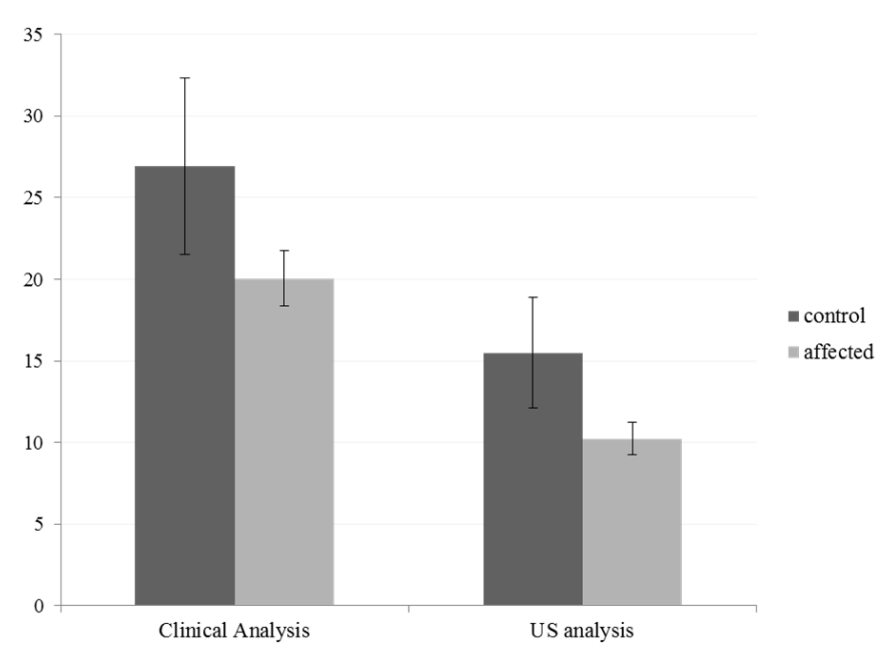

Figure 4. Comparison between Respiratory rate by clinical and US parameters in minutes during respiratory cycle in the control and affected groups. 
inspiration and expiration were higher in the affected group by the analytic methods employed. However, the affected group showed a decrease in the mean plateau compared to the control group (Table 3). It was observed that the clinically assessed HR pattern between groups was comparable to the HR obtained by the respiratory cycle recorded by diaphragmatic mobility through US (Fig.4).

\section{Evaluation of intercostal muscles}

In this study, the displacement of the intercostal muscles during respiration, calculated by ultrasound, had a higher mean during inspiration and expiration in the control group 8.99 and $8.79 \mathrm{~mm}$, respectively, than the affected group values 7.42 and $7.40 \mathrm{~mm}$, respectively (Table 4).

\section{Hematologic values}

The blood levels of the main carriers of oxygen to the organs were analyzed by hemogram: erythrocytes, hemoglobin and hematocrit. The leukocyte levels were also analyzed due to the constant process of tissue necrosis that the respiratory muscles undergo (Table 5).

According to the values found in the analysis, the mean erythrocyte levels were higher by 0.5 in the affected group.

Table 4. Mean of movement (mm) of the intercostal muscles by US during inspiration (Insp) and expiration (Exp) in the control (C) and affected (A) groups

\begin{tabular}{ccc}
\hline & Insp $(\mathrm{mm})$ & $\operatorname{Exp}(\mathrm{mm})$ \\
\hline C1 & 9.86 & 8.93 \\
C2 & 10.33 & 10.1 \\
C3 & 7.09 & 7.44 \\
C4 & 8.64 & 8.68 \\
Mean \pm SD & $8.99 \pm 1,12$ & $8.79 \pm 0.84$ \\
A1 & 7.3 & 7.89 \\
A2 & 8.06 & 6.88 \\
A3 & 6.81 & 7.09 \\
A4 & 7.51 & 7.71 \\
Mean \pm SD & $7.42 \pm 0,44$ & $7.40 \pm 0.42$
\end{tabular}

Table 5. Mean and standard deviation of the laboratory analysis of erythrocytes, hemoglobin, hematocrit and leukocytes of dogs from the control and affected groups

\begin{tabular}{|c|c|c|c|}
\hline Components & Evaluation & Control Group & Affected Group \\
\hline \multirow[t]{5}{*}{ Erythrocytes $\left(\mu^{3}\right)$} & 1 & $6.17 \pm 0.66$ & $6.15 \pm 0.33$ \\
\hline & 2 & $6.05 \pm 0.65$ & $6.40 \pm 0.37$ \\
\hline & 3 & $6.50 \pm 0.48$ & $6.22 \pm 0.29$ \\
\hline & 4 & $6.67 \pm 0.49$ & $6.42 \pm 0.45$ \\
\hline & Mean $\pm S D$ & $6.35 \pm 0.25$ & $6.3 \pm 0.06$ \\
\hline \multirow[t]{5}{*}{ Hemoglobin $(\mathrm{g} / \mathrm{dL})$} & 1 & $14,15 \pm 1.83$ & $14.45 \pm 0.78$ \\
\hline & 2 & $13.7 \pm 2.00$ & $15,10 \pm 0,81$ \\
\hline & 3 & $14,32 \pm 0,99$ & $14.57 \pm 0.78$ \\
\hline & 4 & $15.4 \pm 0.25$ & $15.15 \pm 1.00$ \\
\hline & Mean \pm SD & $14.39 \pm 0.70$ & $14.81 \pm 0.09$ \\
\hline \multirow[t]{5}{*}{ Hematocrit $\left(\mu^{3}\right)$} & 1 & $42.25 \pm 4.76$ & $43.50 \pm 2.69$ \\
\hline & 2 & $40.25 \pm 4.97$ & $44.25 \pm 1.92$ \\
\hline & 3 & $43.25 \pm 2.59$ & $42.50 \pm 1.80$ \\
\hline & 4 & $44.75 \pm 4.26$ & $43.75 \pm 2.86$ \\
\hline & Mean \pm SD & $42.62 \pm 0.94$ & $43,50 \pm 0,46$ \\
\hline \multirow[t]{5}{*}{ Leukocytes $\left(\mathrm{mm}^{3}\right)$} & 1 & $12.92 \pm 3.97$ & $15.2 \pm 3.40$ \\
\hline & 2 & $15.95 \pm 4.58$ & $15.72 \pm 3.48$ \\
\hline & 3 & $15.17 \pm 3.96$ & $15.40 \pm 3.82$ \\
\hline & 4 & $12.50 \pm 3.29$ & $14.52 \pm 2.89$ \\
\hline & Mean \pm SD & $14.15 \pm 0.46$ & $15.37 \pm 0.33$ \\
\hline
\end{tabular}

The hemoglobin level of the animals was higher by 0.4 in the affected group.

The mean values of the hematocrit and leukocytes between groups were also evaluated and showed results within the normal limits.

\section{DISCUSSION}

Ultrasonography is described by many authors as a simple and harmless method for evaluating the diaphragm mobility (Park et al. 2015). As corroborated in the present study, the US method was able to provide data on the respiratory system of the preclinical GRMD model (Oliveira 2012). However, the methodology used in this study differs from previous reported approaches in DMD patients (Zaidman et al. 2010, Jansen et al. 2012) because echogenicity was not used for comparison but only to identify the diaphragm and intercostal muscles.

From the point of view of clinical and morphometric parameters of the thoracic cavity, it should be pointed out that the average of HR values of both groups were within the normal range (Nelson \& Couto 2006). However, the respiratory pattern of the affected animals was found to be below the normal standard. The clinically measured respiratory rate is in accordance with the pattern of respiratory cycles obtained by the diaphragm mobility analysis through the US exam, when comparing the control and affected groups. These results establish the effectiveness of the employed method. At the end of the experiment, the clinical and laboratory data provided results demonstrating the advantage of the US method in characterizing the possible degree of involvement of the respiratory muscles in the dystrophy symptoms. In addition, the evaluation performed was independent of the patient's breathing effort, making this exam important for patients in advanced stages of muscular dystrophy. In addition, present data revealed differentiation in the stages of respiratory cycles between the control and affected groups, showing that this method can be used to compare the clinical evolution of GRMD patients and as a tool for monitoring patients undergoing cell or drug therapy (Oliveira 2012).

The assessments of diaphragmatic mobility showed a difference between groups, in which the average of diaphragm movement (distance) was higher in the normal group and lower in the control group. This decrease in diaphragmatic distance may represent inefficient amplitude of the expanding capacity in the affected group, suggesting a possible condition of muscular exhaustion in animals affected by dystrophy (Cunningham 1999). Previous studies suggested that the reduction in diaphragmatic movement is strongly related to the air trapping parameter (Yamaguti et al. 2007). The degenerative abnormalities that occur in the respiratory muscles lead to changes in the maximum respiratory pressure, causing a restrictive respiratory disorder, which may reduce the lung capacity of the individuals $(\mathrm{Be}-$ zerra et al. 2010).

In the experiment, it was observed that during diaphragmatic movement, the average frequency of inspiration and expiration was lower in the animals of the control group and higher in the animals of the affected group. The- 
se differences are due to the reduced diaphragmatic motion distance, which can trigger inefficient patterns of lung capacity, revealing a parameter of disease progression that may be affected by the degree of weakness of the respiratory muscles (Bezerra et al. 2010). The plateau state presented mean and standard deviation lower in the affected group and higher in the control group. These results may be correlated to the imbalance of the respiratory pattern of the affected group, suggesting a change in the muscle fibers of the diaphragm (Oliveira 2012).

The diaphragmatic mobility in the affected group presents a shorter distance, and the diaphragm shows a reduced plateau state compared to the control group, suggesting that the diaphragm of this group spends more time in motion. This respiratory muscular disfunction may be considered intimately linked to pulmonary ventilation disorders. This situation is consistent with changes in diaphragmatic mobility cited by Azeredo (2002). Voyvoda et al. (2012) established that paralysis and deficit of the diaphragm has multiple etiologies. Diaphragm movement can be affected by conditions of the phrenic nerve tract abnormalities or transmission of the neuromuscular junction, diaphragm muscle diseases and chest and abdomen diseases.

US studies conducted with humans have been developed to evaluate patients with muscular dystrophy. These studies used echogenicity to define the degree of muscular involvement of the patients (Zaidman et al. 2010, Jansen et al. 2012). In the present study, we used a different $B / M$ mode methodology, which was developed to support future research on the use of stem cells, since recent studies have showed promising results for the application of stem cells in the diaphragm muscle in the $m d x$ muscular dystrophy mouse model. Nonetheless, the authors believed that this study should be performed in the GRMD experimental model (Lessa et al. 2012). In all probability the results found in the present study may be useful to aid future experiments with stem cell applications in the respiratory muscles in the GRMD experimental model.

In order to relate the anatomical thoracic cage changes to the breathing of the individuals, the average of IC and EC of the thoracic cage were used. Data found in the control group were IC 71.41 and EC 71.34, which are within the normal breathing pattern. These data may be explained by the contraction of the abdominal and internal intercostal muscles, which increase abdominal pressure, tensing and relaxing the diaphragm, thus reducing the size of the thorax (Cunningham 1999). In the affected group, the observed figures were IC 61.5 and EC 62.5, which show a smaller IC compared to the EC, representing an abnormal pattern of breathing in this group. Applying another parameter, the height and width of the thoracic cavity, the figures were $24.11 \mathrm{~cm}$ and $18.98 \mathrm{~cm}$ respectively for the control group and $21.28 \mathrm{~cm}$ and $15.63 \mathrm{~cm}$ respectively for the affected group. This thoracic change may be due to non-developed physical and anatomical patterns in the affected group of animals compared to the control group.

The clinical analysis revealed that the body temperature of the animals presented an average difference of $0.3^{\circ} \mathrm{C}$ between the affected group (lower) and the control group (higher). This situation may be due to the increased salivation of the affected animals caused by the atrophy of the masticatory muscles. Body temperature decrease may occur through the loss of body electrolytes due to sweating and salivation, as well as by a slow or inefficient basal metabolism (Cunningham 1999, Nelson \& Couto 2006).

In order to assess possible changes in the respiratory system, it was also necessary to evaluate the hemogram and the main blood hemodynamic parameters in both groups. Among the results found, the average of erythrocytes between groups was normal (Matos \& Matos 1988); however, a higher variation by 0.5 was observed in the affected group. Studies have demonstrated that reduced oxygen level (regardless the cause of the deficit) requires a higher number of red blood cells to offset the deficit of oxygen in the body (Cunningham 1999, Santos et al. 2013). The average hematocrit amount between the groups showed normal figures (Matos \& Matos 1988).

The hemoglobin levels of the affected animals were $0.42 \mathrm{~g} / \mathrm{dL}$ higher than those of the control group, although this index was not statistically significant. Hemoglobin is very important in maintaining tissue oxygenation (Matos \& Matos 1988, Cunningham 1999). Leukocytes are essential for the immune and allergic response in mammals (Matos \& Matos 1988, Cunningham 1999, Nelson \& Couto 2006). They are relevant to DMD because muscle changes are always associated with muscle fiber necrosis processes. Therefore, an increase in leukocytes is expected in the affected group. However, the average levels of both groups were within the normal range reported in literature (Cunningham 1999).

The results presented in our study supply important data for analyzing the status of the respiratory muscles during the life of the affected patient. Furthermore, the methods could be applied in humans, especially in clinically debilitated patients, because it is a non-invasive exam that may propose the appropriate timing to perform mechanical ventilation to enhance the patient's survival.

The data obtained in the clinical, hematological and US analyses revealed that the average indices of inspiration, expiration and plateau parameters were lower in the affected group than in the control group. The plateau phase in the affected group is almost nonexistent, indicating that although the diaphragm does not expand, it presents constant mobility, corroborating the clinical changes observed in this group of animals. Therefore, the method of US evaluation may be viable for use as a clinical evaluation parameter, being effective in research intended to improve the respiratory muscles in preclinical DMD models.

\section{REFERENCES}

Ahmad N., Bygrave M., Zordo T., Fenster A. \& Lee T.Y. 2010. Detecting degenerative changes in myotonic murine models of Duchenne Muscular Dystrophy using High-Frequency Ultrasound. J. Ultrassound Med. 29(3):367-375.

Ambrósio C.E., Valadares M.C., Zucconi E., Cabral R., Pearson P.L., Gaiad T.P., Canovas M., Vainzof M., Miglino M.A. \& Zatz M. 2008. Ringo, a Golden Retriever Muscular Dystrophy (GRMD) dog with absent dystrophin but normal strength. Neuromusc. Dis. 18(11):892-893.

Azeredo C.A.C. 2002. Fisioterapia Respiratória Moderna. 44를 ed. Manole, São Paulo. 
Bezerra P.P., Borges A.P.O. \& Brunherotti M.A.A. 2010. Treino muscular respiratório em pacientes com Distrofia Muscular de Duchenne. Neurociência 18(4):491-497.

Bogdanovich S., Perkins K.J., Krag T.O.B. \& Khurana T. 2004. Therapeutics for Duchenne Muscular Dystrophy: current approaches and future directions. J. Mol. Med. 82(2):102-115.

Cunningham J.G. 1999. Tratado de Fisiologia Veterinária. 4ª ed. Guanabara Koogan, Rio de Janeiro.

Finder J.D., Birnkrant D., Carl J., Farber H.J., Gozal D., Iannccone S.T., Kovesi T., Kravitz R.M., Panitch H., Schramm C., Schroth M., Sharma G., Siever L., Silvestri J.M. \& Sterni L. 2004. Respiratory care of the patient with Duchenne Muscular Dystrophy. Am. Thoracic Soc. 170(4):456-465.

Jansen M., Alfen van N., Sanden M.W.G.N., Dijk J.P., Pillen S. \& Groot I.J.M. 2012. Quantitative muscle ultrasound is a promising longitudinal follow-up tool in Duchenne Muscular Dystrophy. Neuromusc. Dis. 22(4): 307-317.

Kennedy J.D., Staples A.J. \& Brook P.D. 1995. Effect of spinal surgery on lung funtion in Duchenne Muscular Dystrophy. Thorax 50(11):11731178.

Kerr M.G. 2003. Exames Laboratoriais em Medicina Veterinária. $2^{\underline{a}}$ ed. Roca, São Paulo.

Lessa T.B., Carvalho R.C., Franciolli A.L., Oliveira L.J., Barreto R.S., Feder D., Bressan F.F., Miglino M.A. \& Ambrósio C.E. 2012. Muscle reorganisation through local injection of stem cells in the diaphragm of mdx mice. Acta Vet. Scandinavica 54(1):73-80.

Matos M.S. \& Matos P.F. 1988. Laboratório Clínico Médico Veterinário. 2a ed. Atheneu, Rio de Janeiro.

Michele D.E. \& Campbell K.P. 2003. Dystrophin glycoprotein complex: Post-translational processing and dystroglycan function. J. Cell Biol. 278(18):15457-15460.

Nelson R.W. \& Couto G.C. 2006. Medicina Interna em Pequenos Animais. 2a ed. Guanabara Koogan, Rio de Janeiro.
Oliveira D.M. 2012. Emprego da ultrassonografia como método de avaliação dos músculos respiratórios em cães Golden Retriever normais e afetados pela distrofia muscular. Dissertação de Mestrado em Ciência Animal, Faculdade de Medicina Veterinária e Zootecnia, Universidade de São Paulo, São Paulo. 76p.

Oliveira D.M., Santos A.C., Bertassoli M.B., Viana D.C., Franco A.A.P. \& Assis-Neto A.C. 2013. Comparative study of the kidneys from dystrophic mice. J. Morphol. Science 30(3):186-190.

Park G-Y., Kim S.-R., Kim Y.W., Jo K.W., Lee E.J., Kim Y.M. \& Im S. 2015. Decreased diaphragm excursion in stroke patients with dysphagia as assessed by M-Mode sonography. Arch. Phys. Med. Rehabil. 96(1):114121.

Santos A.C., Oliveira D.M., Bertassoli B.M., Viana D.C., Vasconcelos B.G. \& Assis-Neto A.C. 2013. Morphologic features from mdx mice spleens, used for Duchenne Muscular Dystrophy Studies. J. Morphol. Science 30(1):21-27.

Sintzoff J.R., Gillard I., Van Gansbeke D., Gevenois P.A., Salmão I. \& Struyven J. 1992. Ultrassound evaluation of soft tissue tumors. J. Belge Radiol. 75(4):276-280.

Voyvoda N., Yucel C., Karatas G., Oguzulgen I. \& Oktar S. 2012. An evaluation of diaphragmatic movements in hemiplegic patients. Brit. J. Radiol. 85(4):411-414.

West J.B. 2002. Fisiologia Respiratória. 6a ed. Manole, São Paulo.

Yamaguti W.P.S., Paulin E., Shibao S., Kodaira S., Chammas M.C. \& Carvalho C.R.F. 2007. Ultrassound evaluation of diaphagmatic mobility in different postures in healthy subjects. J. Bras. Pneumol. 33(4):407-413.

Zaidman C.M., Connolly A.M., Malkus E.C., Florence J.M. \& Pestronk A. 2010. Quantitative ultrasound using backscatter analysis in Duchenne and Becker Muscular Dystrophy. Neuromusc. Dis. 20(12):805-809.

Zatz M., Vainzof M. \& Passos-Bueno M.R. 2000. Limb-girdle muscular dystrophy: Onegy gene with different phenotypes, one phenotype with different genes. Curr. Opn Neurol. 13(5):511-517. 